\title{
A Case of Acute Promyelocytic Leukemia with PML/RARA Translocation Showing Familial $t(9 ; 15)$ (q34;q22)
}

\author{
So Youn Shin, M.D., Sun Hoe Koo, M.D., Kye Chul Kwon, M.D., Jong Woo Park, M.D., \\ Chi Seon Ko, M.D. and Deog Yeon Jo, M.D. ${ }^{1}$
}

Departments of Laboratory Medicine and ${ }^{1}$ Internal Medicine, Chungnam National University Hospital, Daejeon, Korea

\begin{abstract}
We report the unusual case of an APL patient with a familial $t(9 ; 15)(\mathrm{q} 34 ; \mathrm{q} 22)$ and acquired $\mathrm{t}(15 ; 17)$ (q22;q21). This is unique in that the patient had a constitutional abnormality with the same breakpoints as those observed in the tumor clone from the APL. It is unclear if the breakpoint, 15q22, in the constitutional aberration influenced the induction of the PML/RARA translocation in the APL. If a specific translocation in a patient with leukemia does not go away with clinical improvement, a congenital or familial chromosomal abnormality should be considered. Additional patients with similar findings are needed to understand the pathogenesis of these events. (Korean J Hematol 2007;42:428-432.)
\end{abstract}

Key Words: Acute promyelocytic leukemia, Chromosomal translocation, t(9;15), t(15;17), Constitutional chromosomal abnormality

\section{INTRODUCTION}

Acute promyelocytic leukemia (APL) is genetically well characterized by a gene fusion transcript involving the gene for the retinoic acid receptor alpha $(R A R A)$ of chromosome 17 and the $P M L$ of chromosome 15 . The product of the fusion genes, $P M L / R A R A$, maintains the ligandbinding domains of $R A R A$ and blocks the transcription of the genes required for myeloid cell differentiation resulting promyelocytic leukemogenesis. $^{1)}$

Although most APL cases present with classic $t(15 ; 17)$ and some cases with either simple or complex variants of this translocation, involving chromosomes 15, 17 and one or more other chromosomes, such as $\mathrm{t}(15 ; 20 ; 17)(\mathrm{q} 22 ; \mathrm{p} 13 \mathrm{pq} 21), \mathrm{t}(6$;

\footnotetext{
접수 : 2007년 1월 30일, 수정 : 2007년 7월 13일 승인 : 2007년 7월 28일

교신저자 : 구선회, 대전시 중구 대사동 640

우 301-721, 충남대학교병원 진단검사의학과

Tel: 042-220-7798, Fax: 042-257-5365

E-mail:shkoo@cnu.ac.k
}

15;17)(q25;q22;q21), t(2;15;17)(q21;q22;q21), t(1; $15 ; 17)(\mathrm{q} 36 ; \mathrm{q} 22 ; \mathrm{q} 21.1){ }^{2-5)} \mathrm{t}(17 ; 20)(\mathrm{q} 21 ; \mathrm{q} 12), \mathrm{t}(3 ; 17)$ (q26.3; 12$)$ and $\mathrm{t}(5 ; 17)(\mathrm{q} 35 ; \mathrm{q} 21),{ }^{1,6,7)}$ familial or constitutional chromosomal abnormalities associated with hematological malignancies are rare. ${ }^{8)}$

However, variable constitutional chromosomal abnormalities have been steadily presented with a possible to definite association. ${ }^{9)}$ The most frequent abnormality is a constitutional trisomy 8 mosaicism, which is found in $15 \sim 20 \%$ hematological dysplasias and neoplasias. The inversion of chromosomes 8 and trisomy 21 are known to be strongly associated with an increased risk of hematological malignancy. ${ }^{10,11)}$ There is also a report of constitutional 21 trisomy in APL. ${ }^{12)}$

Generally, most trisomies or structural rearrangements those are often observed in cancers

\footnotetext{
Correspondence to : Sun Hoe Koo, M.D.

Department of Laboratory Medicine, Chungnam National University Hospital

640, Daesa-dong, Jung-gu, Daejeon 301-721, Korea

Tel: + 82-42-220-7798, Fax: +82-42-257-5365

E-mail:shkoo@cnu.ac.k
} 
are acquired abnormalities associated with the disease process. However, some specific breakpoints of constitutional translocations observed in some hematological malignancies suggest that the constitutional translocation itself plays a major role in the malignancy process. ${ }^{13)}$ However, in our literature review, there were no other constitutional abnormalities that can provide more clues to understanding the process of leukemogenesis in APL.

We report an unusual case of APL with the classical $P M L / R A R A$ translocation in a patient with constitutional $\mathrm{t}(9 ; 15)(\mathrm{q} 34 ; \mathrm{q} 22)$. It is unclear if the breakpoint, $15 \mathrm{q} 22$, in the constitutional aberration of this patient might have influenced the induction of $P M L / R A R A$ translocation in APL. This is a unique case with a constitutional abnormality with the same breakpoint as those observed in the tumor clone in APL.

\section{CASE REPORT}

A 25-year-old woman was admitted for an evaluation of persistent gum bleeding and epistaxis. She showed menorrhagia, arthralgia, and myalgia, and bruised easily. The hematologic tests showed the following: hemoglobin $9.8 \mathrm{~g} / \mathrm{dL}$, platelet $6 \times 10^{9} / \mathrm{L}$ and a white blood cell count of $18.15 \times 10^{9}$ with $53 \%$ blast cells, $6 \%$ promyelo-

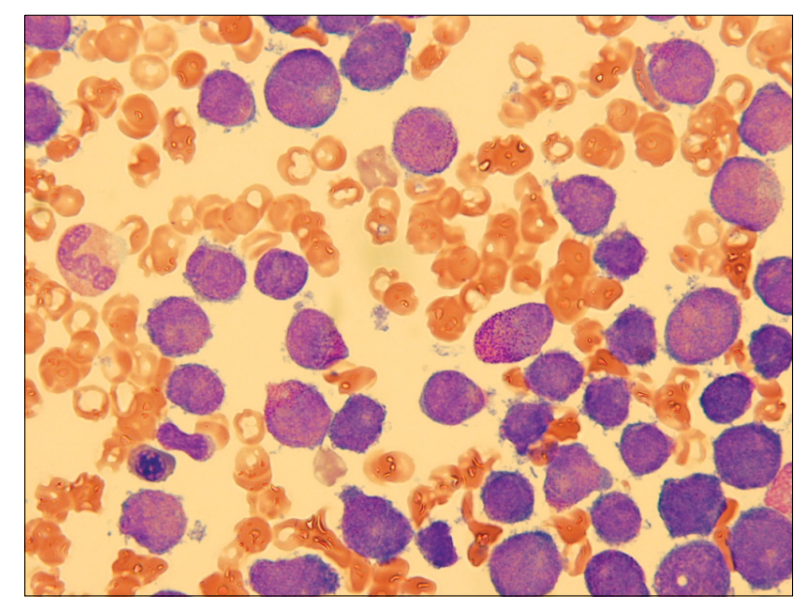

Fig. 1. The blasts are filled with coarse azurophilic granules without prominent Auer rods. cytes, $1 \%$ myelocytes, and $6 \%$ band neutrophils. The FDP and D-dimer were increased by up to $58 \mathrm{ug} / \mathrm{mL}$ and $15.95 \mathrm{ug} / \mathrm{mL}$. The bone marrow biopsy showed a packed marrow with immature cells and in aspirate, the cytoplasms of cells were filled with coarse azurophilic granules without prominent Auer rod (Fig. 1). Immunophenotyping revealed $\mathrm{CD} 13+(91.2 \%), \mathrm{CD} 33+(96.9 \%), \mathrm{MPO}+$ (85.6\%), HLA DR- (4.54\%). A diagnosis of acute promyelocytic leukemia (APL M3) with DIC was made. The patient was treated with Idarubicin and ATRA for induction therapy. After complete remission had been achieved, consolidation therapy was performed 3 times, and she has remained in complete remission since.

The cytogenetic result of her first BM cytogenetic study was 46,XX,t(9;15)(q34;q22), t(15;17)(q22; q21) (Fig. 2). Each allele of chromosome 15 translocated with each chromosome 9 and 17. In FISH study, 99\% cells showed fusion signals of $P M L /$ $R A R A$ (LIS PML/RARA dual color translocation probe; 15q22 LSI PML spectrumOrange/ 17q21.1 LSI RARA spectrumGreen) (Fig. 3). A $P M L /$ $R A R A$ rearrangement was found using reverse transcriptase nested PCR.

After achieving complete remission, $\mathrm{t}(15 ; 17)$ (q22;q21) was no longer found in the karyotype and FISH studies (Fig. 4). However, the $t(9 ; 15)$ (q34;q22) still remained after consolidation chemotherapy. Considering the possibility of a constitutional chromosomal abnormality of $\mathrm{t}(9 ; 15)$ (q34;q22), her healthy family's karyotypes were examined. Her mother and two elder sisters were

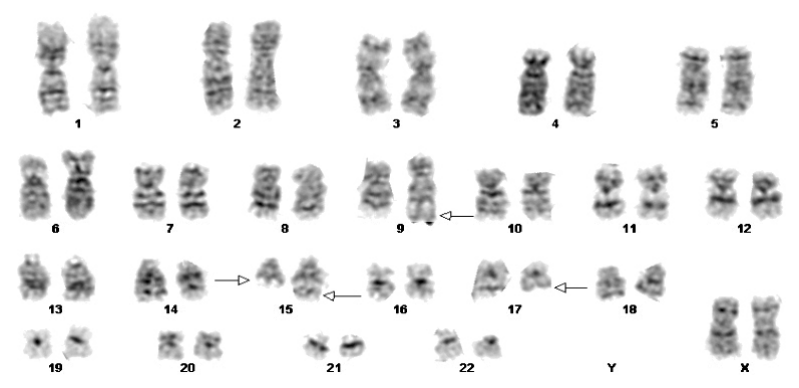

Fig. 2. G-banded karyotype of bone marrow cells showing $46, X X, t(9 ; 15)(q 34 ; q 22), t(15 ; 17)(q 22 ; q 21)$. 


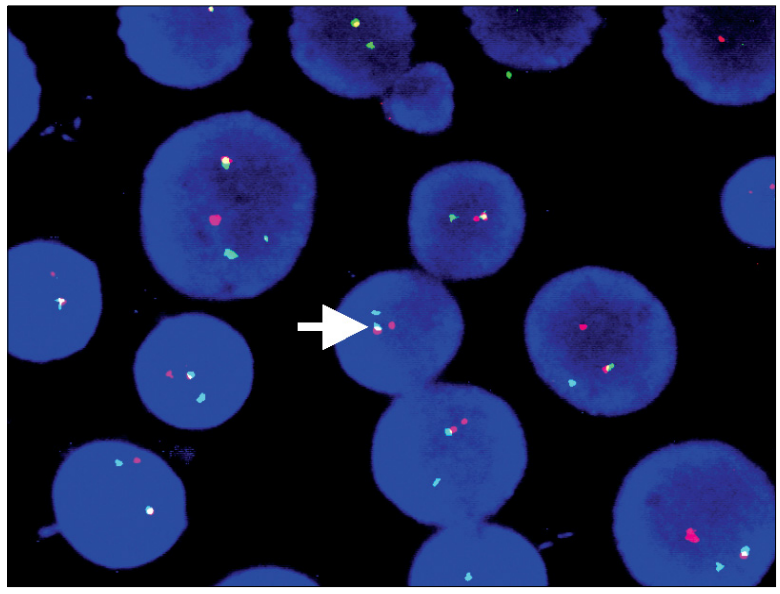

Fig. 3. In FISH study, 99\% cells show fusion signals (white arrow) of PML/RARA (LIS PML/RARA dual color translocation probe;15q22 LSI PML spectrumOrange/17q21.1 LSI RARA spectrumGreen).

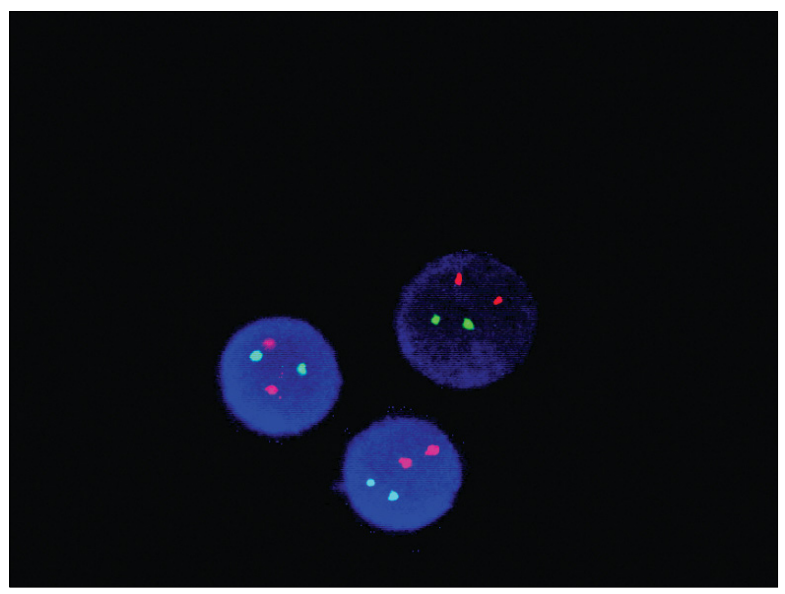

Fig. 4. After treatment, follow up FISH studies show no fusion signal of PML/RARA (LIS PML/RARA dual color translocation probe;15q22 LSI PML spectrumOrange/17q21.1 LSI RARA spectrumGreen).

included for the cytogenetic analysis of peripheral blood. Her father was deceased. In addition, her peripheral blood was evaluated for the karyotype.

The cytogenetic analysis showed $\mathrm{t}(9 ; 15)(\mathrm{q} 34 ; \mathrm{q} 22)$ in all three families' and her peripheral blood, which confirming that $\mathrm{t}(9 ; 15)$ (q34;q22) was a constitutional and familial rearrangement (Fig. 5). Metaphase FISH study of the patient's peripheral blood with LIS PML/RARA dual color translocation probe showed that the two Orange PML

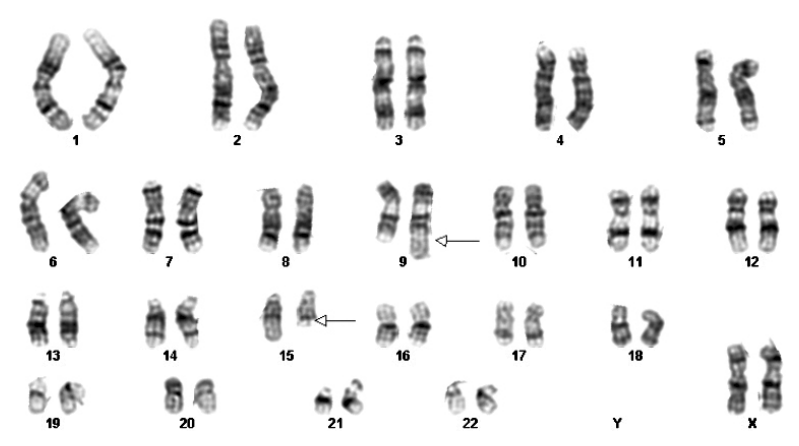

Fig. 5. G- banded karyotype of the patient's mother's peripheral blood showing $t(9 ; 15)(q 34 ; q 22)$.

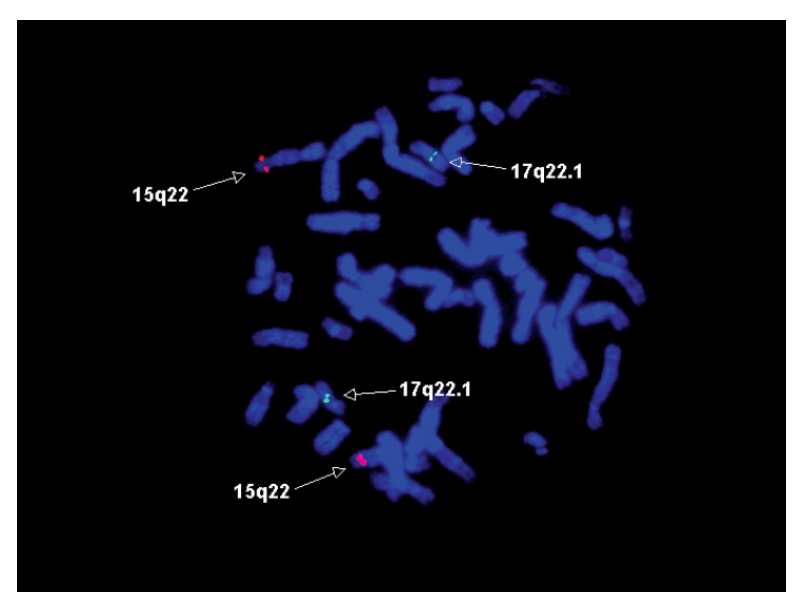

Fig. 6. Metaphase FISH study of the patient's peripheral blood shows a PML probes hybridize with q34 of chromosome 9 (LIS PML/RARA dual color translocation probe; 15q22 LSI PML spectrumOrange/17q21.1 LSI RARA spectrumGreen).

probes hybridize with each different chromosome locus; q22 of a normal allele of chromosome 15 and q34 of chromosome 9 (LIS PML/RARA dual color translocation probe; 15q22 LSI PML spectrumOrange/17q21.1 LSI RARA spectrumGreen) (Fig. 6).

\section{DISCUSSION}

The identification of constitutional chromosome anomalies is important in some specific malignancies including neurofibromatosis, retinoblastoma and Wilm's tumor because they may help to determine the location of the DNA sequences involved in the genetic predisposition. ${ }^{14-17)}$ 
Variable constitutional chromosomal abnormalities have been reported with a possible to definite association with hematologic malignancies, including trisomy 8 , trisomy $21 .^{10-12)}$ In addition to these aneuploidy or large defects in chromosomes, constitutional structural rearrangements also have been reported, suggesting the association with hematologic malignancies. One of the cases was a case with constitutional and familial inv(8), three of the five carriers have a diagnosed clinical disease: ANLL-M7, ITP and breast carcinoma. In the case of acute nonlymphocytic leukemia with a constitutional inv(4)(p16q26) coding murine leukemia viral (v-raf) oncogene, pseudogene 1 and IL-2 gene, the author said activation of the genes could have played a role in the pathogenesis of the patient's leukemia. ${ }^{18)}$ Mozziconacci et al. presented 4 cases of constitutional balanced pericentric inversion of chromosome X, 2 and 5 with or without acquired chromosomal aberration in myeloid malignancies, suggesting influence of the constitutional pericentric inversion to hematologic malignancies. ${ }^{19)}$

In particular, constitutional translocations with the break points that harbor the genes in charge of a specific type of leukemia also have been reported in several patients with hematological malignancies as in this presented case. In the case of Ganly et al. of myelodysplastic syndrome and transforming to acute myelocytic leukemia with constitutional $\mathrm{t}(5 ; 7)(\mathrm{q} 11 ; \mathrm{p} 15)$, the disruption of bands $5 \mathrm{q} 11$ or $7 \mathrm{p} 15$, which are frequently observed in MDS, AML as acquired translocations. ${ }^{20)}$ Becher et al. and Qian et al. reported cases of CML with constitutional Robertsonian tranlocation attended by Philadelphia chromosome. ${ }^{21,22)}$ Constitutional t $(5 ; 11)(\mathrm{p} 15.3 ; \mathrm{q} 23)$ attended by acute lymphoblastic leukemia and $\mathrm{t}(8 ; 21)$ with acute nonlymphocytic leukemia in a Down syndrome were also reported. ${ }^{23)}$ As a chromosomal fragile site, constitutional chromosomal aberrations harboring the genes involved pathogenesis in hematologic malignancies would provide more information to discover their unknown pathogenesis.
In this case, the break point $15 \mathrm{q} 22$ of constitutional $\mathrm{t}(9 ; 15)(\mathrm{q} 34 ; \mathrm{q} 22)$ was located proximally from the general breakpoint of $15 \mathrm{q} 22$ in APL in metaphase FISH study, which were observed as same breakpoint in G-banding. To our knowledge, this is the first case of constitutional $\mathrm{t}(9 ; 15)(\mathrm{q} 34 ; \mathrm{q} 22)$ attended by APL. There are just two constitutional $\mathrm{t}(9 ; 15)$ cases associated with Prader-Willi syndrome and unknown psychomotor retardation syndromes. ${ }^{24,25}$ Those were not a sole aberration and the break points were different from our case, as the former was 45,XY, $-9,-15,+\operatorname{der}(9), \mathrm{t}(9 ; 15)(9$ pter- $>9 \mathrm{q} 34:: 15 \mathrm{q} 11->15 \mathrm{qte}$ r) and the later was $46, \mathrm{XY},-9,-15,+\mathrm{i}(9 \mathrm{P}), \mathrm{t}(9 ; 15)$ (q11;p12). The carrier family members showed normal appearance and mental status.

This case showed a clinical response and there was no difference in the clinical progress and outcome with cases of APL with the typical $t(15 ; 17)$. Although, the role of the constitutional $t(9 ; 15)$ (q34;q22) and the association with PML/RARA translocation in this case are unclear, the patient was found to have an unusual breakpoint that harbored the PML gene.

\section{요 약}

급성전골수성백혈병의 특징적인 $\mathrm{t}(15 ; 17)(\mathrm{q} 22 ; \mathrm{q} 21)$ 에 동반되어 나타난 선천성 $\mathrm{t}(9 ; 15)(\mathrm{q} 34 ; \mathrm{q} 22)$ 최초의 1 예를 보고하는 바이다. 이 환자에서 보여진 선천성 $\mathrm{t}(9 ; 15)$ (q34;q22)에서의 breakpoint $15 \mathrm{q} 22$ 가 PML/ RARA를 유도하였는지는 알 수 없지만, 질병에 특 이적인 전좌에 동반된 다른 전좌들이 치료에 반응 하지 않는 경우 선천성 및 가족성 염색체 이상의 가 능성을 고려하여야 하며, 질병에 특이적인 전좌와 동일한 breakpoint를 공유하는 선천적 염색체 이상 에 대한 보고들은 질병의 병인을 이해하는 데 도움 이 될 것으로 생각한다.

\section{REFERENCES}

1) Garcia-Casado Z, Cervera J, Valencia A, et al. A $\mathrm{t}(17 ; 20)(\mathrm{q} 21 ; \mathrm{q} 12)$ masking a variant $\mathrm{t}(15 ; 17)(\mathrm{q} 22 ; \mathrm{q} 21)$ in a patient with acute promyelocytic leukemia. 
Cancer Genet Cytogenet 2006;168:73-6.

2) Yamamoto K, Hamaguchi H, Nagata K, Kobayashi M, Takashima T, Taniwaki M. A new complex translocation $(15 ; 20 ; 17)(\mathrm{q} 22 ; \mathrm{p} 13 ; \mathrm{q} 21)$ in acute promyelocytic leukemia. Cancer Genet Cytogenet 1998;101: 89-94.

3) Eclache V, Viguie F, Frocrain C, et al. A new variant $\mathrm{t}(6 ; 15 ; 17)(\mathrm{q} 25 ; \mathrm{q} 22 ; \mathrm{q} 21)$ in acute promyelocytic leukemia: fluorescence in situ hybridization confirmation. Cancer Genet Cytogenet 2005;159:69-73.

4) Fujishima M, Takahashi N, Miura I, et al. A PML/ RARA chimeric gene on chromosome 2 in a patient with acute promyelocytic leukemia (M3) associated with a new variant translocation: $\mathrm{t}(2 ; 15 ; 17)(\mathrm{q} 21 ; \mathrm{q} 22$; q21). Cancer Genet Cytogenet 2000;120:80-2.

5) Osella P, Wyandt H, Vosburgh E, Milunsky A. Report of a variant $\mathrm{t}(1 ; 15 ; 17)(\mathrm{p} 36 ; \mathrm{q} 22 ; \mathrm{q} 21.1)$ in a patient with acute promyelocytic leukemia. Cancer Genet Cytogenet 1991;57:201-7.

6) Macedo Silva ML, Land M, Heller A, et al. New rearrangement $\mathrm{t}(3 ; 17)(\mathrm{q} 26.3 ; \mathrm{q} 12)$ in an AML patient with a poor outcome. Oncol Rep 2005;14;663-6.

7) Nicci C, Ottaviani E, Luatti S, et al. Molecular and cytogenetic characterization of a new case of $\mathrm{t}(5 ; 17)$ (q35;q21) variant acute promyelocytic leukemia. Leukemia 2005;19:470-2.

8) Horwitz M. The genetics of familial leukemia. Leukemia 1997;11;1347-59.

9) Hecht F. Risks of hematologic malignancy with constitutional chromosome abnormalities. Cancer Genet Cytogenet 1987;24:375-7.

10) Maserati E, Aprili F, Vinante F, et al. Trisomy 8 in myelodysplasia and acute leukemia is constitutional in 15 20\% of cases. Genes Chromosomes Cancer 2002;33:93-7.

11) Weinstein HJ. Congenital leukaemia and the neonatal myeloproliferative disorders associated with Down's syndrome. Clin Hematol 1978;7:147-54.

12) Kurkjian C, Patel S, Kamble R, Dunn ST, Kern W, Kharfan-Dabaja MA. Acute promyelocytic leukemia and constitutional trisomy 21. Cancer Genet Cytogenet 2006;165:176-9.

13) Panani AD, Pappa V, Raptis SA. Novel constitutional translocations $\mathrm{t}(3 ; 5)(\mathrm{p} 25 ; \mathrm{q} 22)$ and $\mathrm{t}(1 ; 14)(\mathrm{p} 31 ; \mathrm{q} 21)$ in patients with acute leukemia. Ann Hematol 2004; 83:156-9.

14) Ledbetter DH, Rich DC, O’Connell P, Leppert M, Carey JC. Precise localization of NF1 to $17 q 11.2$ by balanced translocation. Am J Hum Genet 1989; 44:20-4.

15) Turleau C, de Grouchy J, Chavin-Colin F, et al. Cytogenetic forms of retinoblastoma: their incidence in a survey of 66 patients. Cancer Genet Cytogenet 1985;16:321-34.

16) Riccardi VM, Sujansky E, Smith AC, Francke U. Chromosomal imbalance in the Aniridia-Wilms' tumor association: 11p interstitial deletion. Pediatrics 1978;61:604-10.

17) Yunis JJ, Ramsay N. Retinoblastoma and subband deletion of chromosome 13. Am J Dis Child 1978; 132:161-3.

18) Sreekantaiah C, Han T, Baer MR, Sandberg AA. Acute nonlymphocytic leukemia in a patient with a constitutional inv(4). Cancer Genet Cytogenet 1989; 39:119-23.

19) Mozziconacci MJ, Sobol H, Philip N, et al. Constitutional balanced pericentric inversions of chromosome $\mathrm{X}, 2$, and 5 in myeloid malignancies. Cancer Genet Cytogenet 1998;107:28-31.

20) Ganly P, McDonald M, Spearing R, Morris CM. Constitutional $\mathrm{t}(5 ; 7)(\mathrm{q} 11 ; \mathrm{p} 15)$ rearranged to acquire monosomy $7 q$ and trisomy $1 \mathrm{q}$ in a patient with myelodysplastic syndrome transforming to acute myelocytic leukemia. Cancer Genet Cytogenet 2004;149: 125-30.

21) Becher R, Mahmoud HK, Schaefer UW, Schmidt CG. Ph-positive CML in a family with a constitutional Robertsonian translocation 14;15. Cancer Genet Cytogenet 1985;18:229-34.

22) Qian J, Xue Y, Sun J, et al. Constitutional Robertsonian translocations in (9;22)-positive chronic myelogenous leukemia. Cancer Genet Cytogenet 2002;132: 79-80.

23) Swan J, Lee CL, Yhap M. Constitutional t( $5 ; 11)$ (p15.3;q23) in an adolescent male with acute lymphoblastic leukemia. Cancer Genet Cytogenet 2001; 128:178-80.

24) Fraccaro M, Zuffardi O, Buhler E, et al. Deficiency, transposition, and duplication of one $15 q$ region may be alternatively associated with Prader-Willi (or a similar) syndrome. Analysis of seven cases after varying ascertainment. Hum Genet 1983;64:388-94.

25) Sandig KR, Mucke J, Veit H. Trisomy 9p resulting from de novo $9 / 15$ translocation and a $9 p$ isochromosome. Hum Genet 1979;52:175-8. 